\title{
Article \\ Slope Shape Optimization of Water Reservoirs Formed Due to the Reclamation of Post-Mining Excavations
}

\author{
Urszula Kaźmierczak*(D), Monika Bartlewska-Urban (D) and Paweł Strzałkowski \\ Department of Mining, Faculty of Geoengineering, Mining and Geology, \\ Wroclaw University of Science and Technology, Wybrzeże Wyspiańskiego 27, 50-370 Wrocław, Poland; \\ monika.bartlewska@pwr.edu.pl (M.B.-U.); pawel.strzalkowski@pwr.edu.pl (P.S.) \\ * Correspondence: urszula.kazmierczak@pwr.edu.pl
}

Citation: Kaźmierczak, U.; Bartlewska-Urban, M.; Strzałkowski, P. Slope Shape Optimization of Water Reservoirs Formed Due to the Reclamation of Post-Mining

Excavations. Appl. Sci. 2022, 12, 1690. https://doi.org/10.3390/ app12031690

Academic Editor: Tiago Miranda

Received: 15 December 2021

Accepted: 3 February 2022

Published: 7 February 2022

Publisher's Note: MDPI stays neutral with regard to jurisdictional claims in published maps and institutional affiliations.

Copyright: (C) 2022 by the authors. Licensee MDPI, Basel, Switzerland. This article is an open access article distributed under the terms and conditions of the Creative Commons Attribution (CC BY) license (https:// creativecommons.org/licenses/by/ $4.0 /)$.

\begin{abstract}
Reclamation of post-mining areas is one of the most important duties of an entrepreneur involved in mining mineral resources with the use of surface techniques. There are various forms of reclamation activities that depend on the chosen reclamation direction and intended function of the reclaimed object as well as from the type of the mined mineral. When there is water present in the mining excavation, we are talking about the aquatic direction of reclamation. This particular type of post-mining area requires a particular shape-especially if its intended future function is recreational. This research addresses optimization-related analyses and calculations of slope inclination in water reservoirs formed in post-mining excavations of both clastic and clay rock raw materials. Considering the conditions of stability and load-bearing capacity of water reservoir slopes, their optimum slopes were determined using the FlexPDE v 6.0 program, based on a two-dimensional elastoplastic model from the Coulomb-Mohr criterion. The inclinations of 1:5 and 1:15 are proposed, respectively, for the above-waterline and below-waterline slopes that serve a beach function. Slopes that do not serve a beach function are proposed to have an inclination of 1:2. Obviously, the strength conditions in the soil medium as well as the comfort of users were key drivers when it comes to selection of the slope inclinations.
\end{abstract}

Keywords: reclamation of post-mining excavations; optimization; mathematical modelling; soil mechanics; Coulomb-Mohr criterion; slope stability

\section{Introduction}

The final phase of each mining projects is, last but definitely not the least, reclamation of a post-mining area. Reclamation means providing or restoring functional properties to post-mining areas after the mineral production process is finished. It is an obligation that each mining entrepreneur involved in a mining activity should be aware of. However, the scope of the reclamation requirement varies and depends on the advancement of a mining activity and the accumulation of the obligations. Reclamation as a concept in mining is expressed in the form of a reclamation direction. Normally, the reclamation direction should be precisely defined with respect to the expected future function of the area, and this requirement influences the scope (and the cost) of basic reclamation. Reclamation costs are an element of the operating costs of a mining company (Figure 1). Due to the specific character of rock mining, entrepreneurs frequently render the mining area available for reclamation only at the end of the mine life, i.e., in the last phase of mining operations (the closure phase). In many cases, this last phase is the least profitable in the mine's typical lifecycle-the production lowers so the revenue flow from mining production significantly decreases or even completely stops. At the same time, the expenditures related to the reclamation tasks which occur at that time may be even as high as the costs of the deposit development (the pre-investment phase) [1-4]. Therefore, reclamation works should be performed at the stage of deposit extraction, on the condition that they remain in line with 
the planned future function of the reclaimed area. In many cases, this last phase is the least profitable in the mine's typical lifecycle-the production lowers so the revenue flow from mining production significantly decreases or even completely stops. Additionally, appropriate planning of the scope of such works to be performed already at the mineral production stage may even result in decreasing the final reclamation costs. An example can be found in the aquatic direction of reclaiming a post-mining excavation which is intended to serve as a recreational area with a water reservoir for bathing, sunbathing, and recreational activities in the greenery. The literature [4-8] mentions the preferred profiles for bathing areas in old excavations of rock raw materials. However, the slope inclinations suggested in the above publications (1:5-1:10 for any slope serving as a beach and 1:30-1:60 for any underwater slope) require a very broad scope of basic reclamation works, and this fact entails significant financial expenditures. Considering the fact of shaping the reservoir slopes in the final phase of the mine liquidation, when the income is reduced, it is a big financial challenge. Moreover, the literature does not provide justification for the proposed slopes in terms of soil stability as well as for the comfort concerns. Therefore, the aim of the research presented in this article is to propose and optimize the reclamation works (change in slope inclination) related to the inclinations of slopes of water reservoirs used as bathing areas considering the safety standards and comfort requirements but also the economical dimension of such a project. It is also worth noting that such an optimization may bring an additional benefit by decreasing the scope of works, and thus also the reclamation costs.

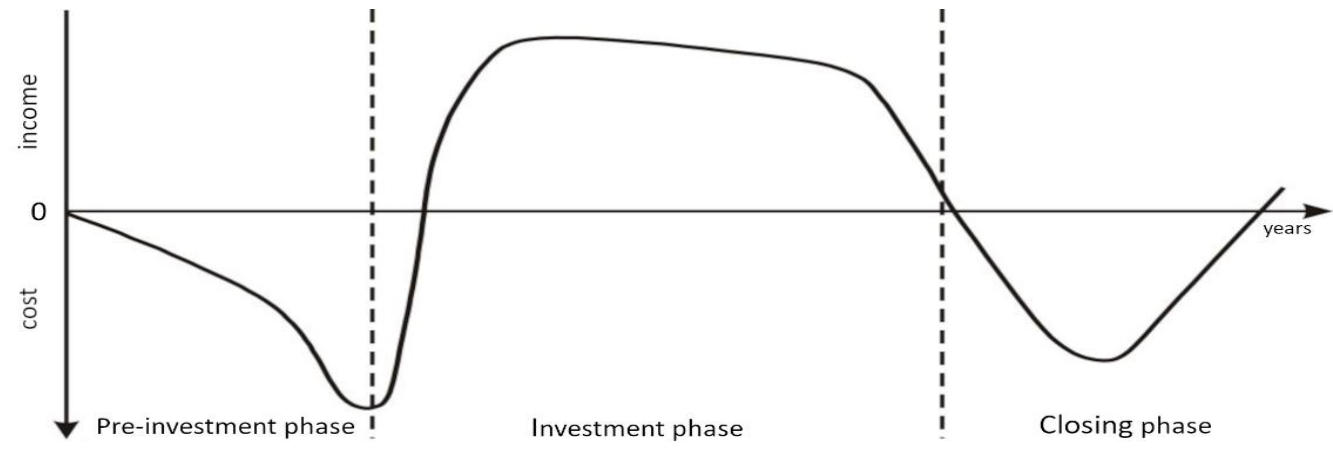

Figure 1. Schematic diagram of financial flows during the entire mine life cycle (own material based on Paulo [9]).

\section{Requirements of Aquatic Reclamation with Recreational Function}

In the case of an aquatic reclamation direction, the reclaimed objects may serve various (i.e., from recreational to industrial) functions. However, the main focus in this article is on the reclamation in the aquatic direction, with the use of an area for recreational and leisure activities or water sports. In the case of such objects, an additional advantage may result from arranging green recreational spaces around such objects, so as to improve the functionality of such an object.

The literature indicates that the aquatic reclamation direction in the technical (basic) phase is performed by means of regulating hydrogeological conditions (including the construction of the necessary hydrotechnical objects and devices), building or rebuilding access roads, reconstructing the layer of fertile soil with the use of technical methods, separating toxic deposits, and moving ground masses, which includes shaping the relief of the reclaimed land and reinforcing the slopes [10-17]. In addition, prior to the proper technical reclamation works, several preparatory and clearing tasks must be performed, such as: removing extra vegetation, demolishing the remaining parts of buildings, and clearing the rubble and debris from the demolished buildings or storing it in a designated location.

Technical reclamation in the aquatic direction with a recreational function (a bathing area) consists in shaping stable slopes, which depend on the physical and mechanical properties of the ground. Designing such a reservoir is possible in the case of clay and 
clastic raw materials. This reservoir development direction requires at least the second class of water quality and limited water table amplitude fluctuations $(<0.5 \mathrm{~m})$. The depth of a recreational reservoir should be at least three meters. Moreover, such a reservoir should have an approximately $40 \mathrm{~m}$ above-water land strip with an inclination of 1:5 to 1:10 and serving as a beach, and a gentle descent to the water, i.e., an underwater slope 50-100 m in width with an inclination of 1:30 to 1:60. The slopes should also be covered with a layer of sand or gravel $5-15 \mathrm{~cm}$ in thickness. A recreational reservoir should also have a dedicated shallow area for non-swimmers. Its surface should be at least 4 ha and its maximum depth-1.5 $\mathrm{m} \mathrm{[4-6].}$

Typical recreational reservoirs have a defined beach area, while the remaining part of the reservoir may be used for fishing or water sports, e.g., sailing or diving. Such objects have different requirements which mostly depend on the technical and geological conditions. The inclination of the above-water slopes which are not beaches should be 1:2 or 1:3 for clastic rocks and 1:1.5 or 1:2 for clays, while in the case of underwater slopes, it should be $1: 5[5,7,8]$. Figure 2 is a schematic view of a bathing area (a lido) located in an old excavation of rock raw materials.

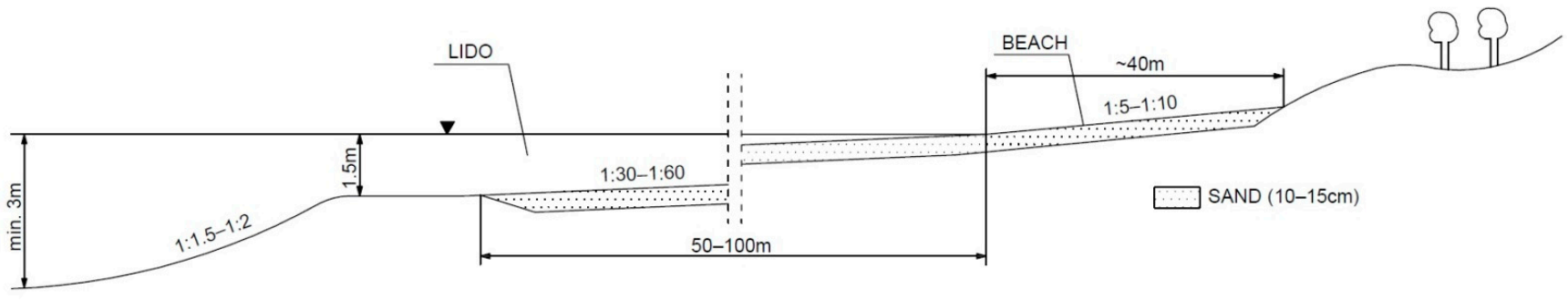

Figure 2. Profile of a lido in an old excavation pit of rock raw materials (own material based on Uberman and Uberman [4]).

Another method for the reclamation of water-filled excavations resulting from the extraction of rock materials is to create fishing and watersport facilities. Reservoirs for diving should have a varied bed shape and reservoirs for sailing should have a considerable depth and area. Reservoirs can also be a landscape feature that increases the value of the area. The requirements regarding slope inclinations are in such a case similar to the inclinations of above-water and underwater slopes which do not serve as beaches in recreational reservoirs.

Typically, reclamation in the aquatic direction is performed along with other directions of future land use (agricultural, forest, or green areas). The reclamation of areas adjacent to a water reservoir should involve the restoration of soil, for example, with the use of the technical soil restoration method. It consists in the covering of barren ground with a layer of fertile soil or with formations stimulating the soil development and plant vegetation [18].

The last stage of the technical reclamation process in the aquatic direction is to build access roads, as well as pedestrian and cycle paths in order to make the reclaimed area accessible. When reclaiming water reservoirs, safety measures must be accounted for. Therefore, reservoir slopes not intended for direct access must be protected by installing fences or growing special plants, for instance bushes.

The biological phase of the reclamation process is limited in the case of aquatic direction. It involves ensuring slope stability by providing a biological enforcement lining, as well as initiating and stimulating hydrobiological processes. The reinforcement lining of reservoir slopes can be divided into an upper part (typically the steeper strip of the slope) and the lower part. The border between the two parts is defined by the groundwater table. After performing agricultural works and applying mineral or organic fertilizer, the upper part of the slope and the protective buffer zone are sown with legume plants which form a humus and anti-erosion layer. In the final stage of the biological reclamation, the slope is covered with xerophilous plants (e.g., black locust, common alder, etc.). In the lower part of the slope, only hydrophilic plants are introduced (e.g., common reed, cattail, 
etc.). The biological reclamation is finished by maintaining the plants, i.e., by removing weeds, loosening the soil around the seedlings and providing fertilizer to the plants in the areas surrounding the reservoir. If some plants wither, they should be replaced with new seedlings.

\section{Optimization of Reclamation Works in the Aquatic Direction}

The excavation and water are recognized as two of the main factors that cause slope instability. The stress field adjustment and rock-soil mass deformation triggered by excavation unloading may result in primary crack expansion and new crack generation in the slope. Meanwhile, water infiltration can promote the propagation of cracks, increase the rock-soil mass weight, and reduce the rock-soil mass shear strength [19-22]. An optimization of the scope of reclamation works with respect to the shaping of the reservoir slopes mainly involves defining the limit values of their stability and load-bearing capacity. The stability and load-bearing capacity of post-mining slopes can be determined by rock strength models, which are generally parameterized using estimates of rock properties [22-25]. The growing popularity of computer applications and of the finite element method results from the possibility to subject an engineering problem to a complex analysis in successive construction phases. Such a complex approach allows a single calculation process to include analyses of deformations and load-bearing capacities, while also taking into account the geometrical variability of a particular issue, the changes to boundary conditions during the construction, as well as the complicated interactions between stiff structural elements and the subsoil. The description of the material in each of the soil layers can be adjusted to the type of the analyzed problem by using more or less complex constitutive models. However, the quality and accuracy of each computational analysis is limited by the scope of the input data. This fact applies primarily to the parameters of the identified soil layers but also to the system of the layers. The mechanical parameters of the soil are identified mostly on the basis of empirical correlations with the parameters of the soil condition. The basic set of strength parameters provided to geotechnical engineers for the purpose of computational analyses includes the effective angle of internal friction $\varphi$ and the effective cohesion $c$. Ground stiffness is described with the use of the Hooke linear elasticity. Despite employing the elasticity theory in the calculations, an assumption is typically made that the values of the identified parameters allow for the non-linear effects which occur in the soil prior to the mobilization of the full strength or before an assumed reference stress is reached. The constitutive model constructed in such a manner is referred to in the literature as the Coulomb-Mohr model and is the basic model implemented in computer programs to solve problems of initial and limit conditions in geotechnology in order to identify the ultimate limit state of shear strength [26,27].

The condition of plasticity resulting from the Coulomb-Mohr criterion can be noted most simply with the use of the main stress component as:

$$
\mathrm{F}_{\mathrm{MC}}=1 / 2\left(\sigma_{\max }-\sigma_{\min }\right)+1 / 2\left(\sigma_{\max }-\sigma_{\min }\right) \sin \phi-c \cos \phi=0,
$$

where, $\sigma_{\max }-\sigma_{\min }$ - the smallest and the greatest main stress, respectively, based on an assumption that the compressive stresses have negative values [28].

The calculations were performed with the use of the FlexPDE v 6.0 software, based on a two-dimensional elastic model from the Coulomb-Mohr criterion for two materials: coarse sand and clay. The parameters of these two media are shown in Table 1, and the shape of the modeled area is shown in Figure 3. The inclination of the above-water land strip was assumed to be at the maximum acceptable level, i.e., 1:5.

The presented parameters were obtained from external laboratory tests. For the calculations in the Coulomb-Mohr model, effective parameters were assumed. 
Table 1. Parameters of the media.

\begin{tabular}{|c|c|c|c|c|c|c|c|c|c|c|c|c|c|}
\hline Soil & $\gamma_{s}$ & $n$ & $\rho$ & $I_{L}$ & $I_{D}$ & $\gamma$ & $\gamma^{\prime}$ & $\phi^{\prime}$ & $c^{\prime}$ & $E$ & $v$ & $\gamma_{s}$ & $n$ \\
\hline - & $\mathrm{kN} / \mathrm{m}^{3}$ & - & $\mathrm{kg} / \mathrm{m}^{3}$ & - & - & $\mathrm{kN} / \mathrm{m}^{3}$ & $\mathrm{kN} / \mathrm{m}^{3}$ & $\circ$ & $\mathrm{kPa}$ & $\mathrm{MPa}$ & - & - & $\mathrm{kN} / \mathrm{m}^{3}$ \\
\hline Clay & 27.2 & 0.5 & 1390 & 0.4 & - & 13.6 & 8.7 & 9.5 & 32.5 & 8.0 & 0.37 & 27.2 & 0.5 \\
\hline Sand & 26.5 & 0.3 & 1890 & - & 0.5 & 18.5 & 11.7 & 35.0 & 0 & 80.0 & 0.25 & 26.5 & 0.3 \\
\hline
\end{tabular}

$\gamma_{s}$-specific weight of the soil skeleton, $n$-porosity, $\rho$-soil bulk density, $I_{L}$-liquidity index, $I_{D}$-density index $\gamma$-specific weight of the soil, $\gamma^{\prime}$-effective weight; $\phi^{\prime}$-internal angle of friction, $c^{\prime}$-cohesion, E-Young's modulus, $v-$ Poisson ratio.

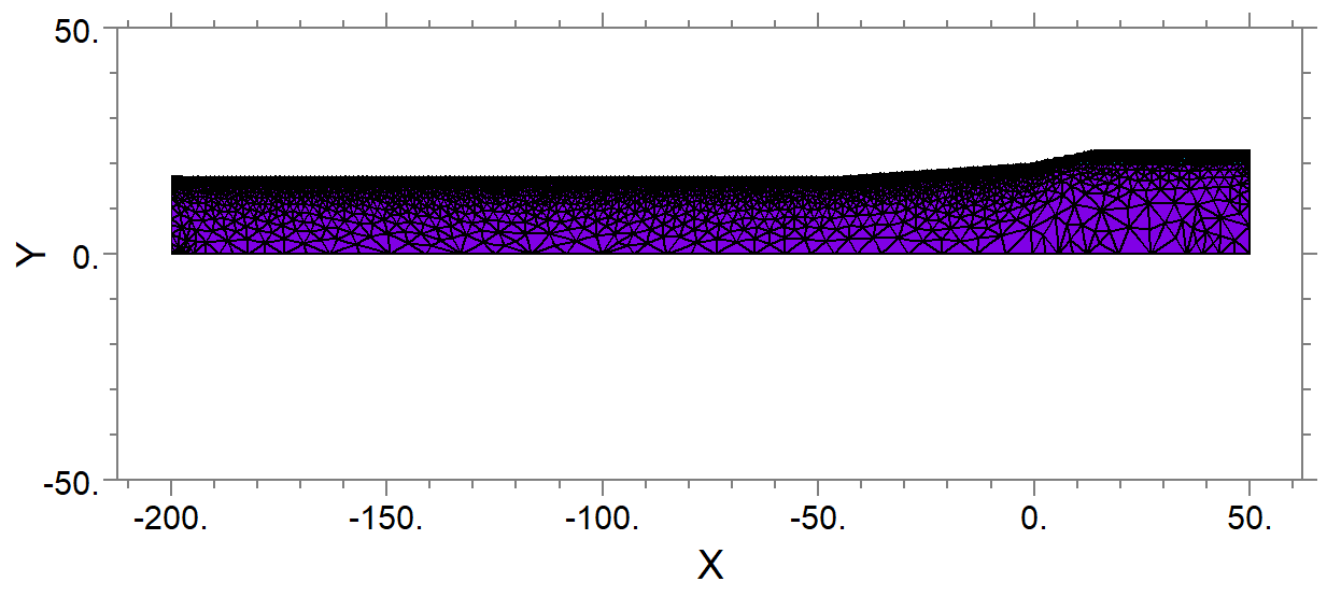

Figure 3. The modeled area with the final computational mesh.

\subsection{Inclination Optimization for Slopes Functioning as Beaches}

The inclination of a slope functioning as a beach should be shaped with allowance for the stability conditions, as well as for the safety and comfort concerns. Its basic function is to provide access and gentle descent to the bathing area (lido) and to facilitate leisure activities.

In order to verify whether beach stability is possible for underwater slopes having an inclination greater than the recommended 1:60-1:30, the stability was calculated for several inclination ratios: 1:30, 1:25, 1:20, and 1:15.

Figures 4 and 5 show horizontal stresses for clay and for coarse sand, respectively. The analyzed increase in the inclination ratio did not influence the results of the simulations. From the perspective of slope stability, calculations of the Coulomb-Mohr potential are more important. The determination of the medium's plasticization zones was performed based on the Coulomb-Mohr potential. The negative value of the potential defines the areas where the area is stable. Where the potential is positive, the shear strength has been exceeded. Calculations are shown for both types of soil in Figures 6 and 7. The potential sign was not observed to reverse in any area, which suggests good stability conditions for both underwater and above-water slopes, for both media. 


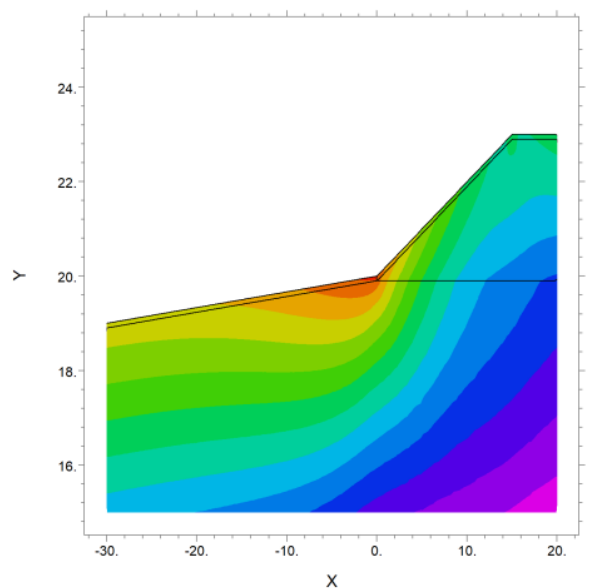

(a)

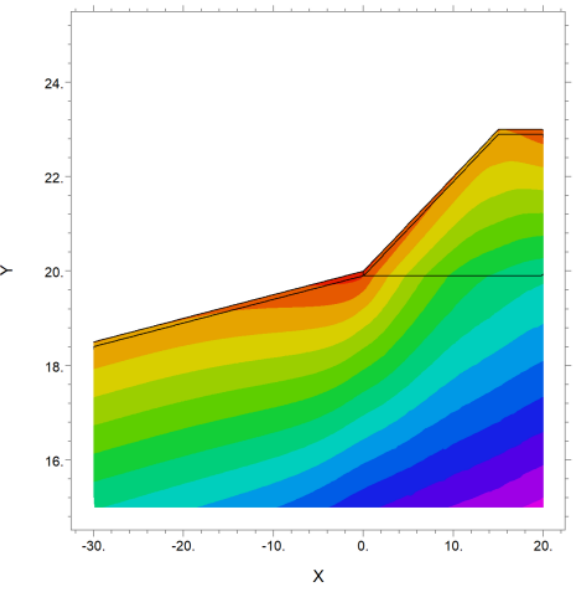

(c)

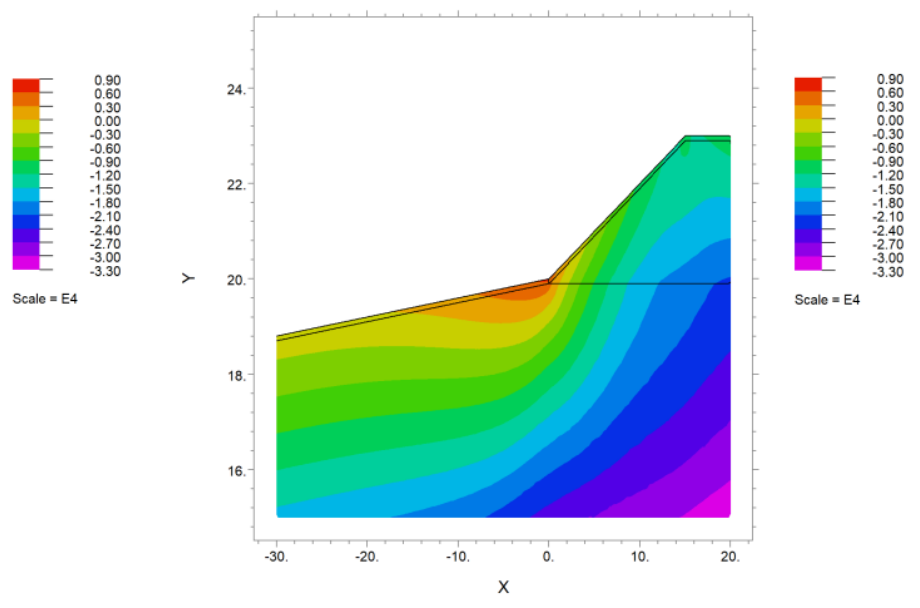

(b)

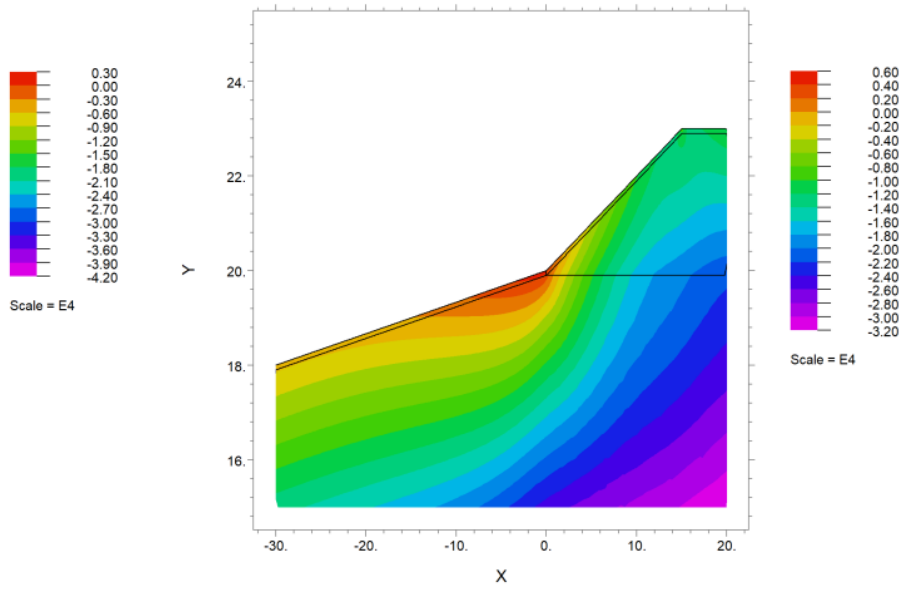

(d)

Figure 4. Horizontal stresses for the sand-type subsoil, for underwater slope inclinations of: (a) 1:30, (b) 1:25, (c) 1:20, (d) 1:15 (negative values indicate compressive stresses in $\mathrm{Pa}$, and positive values-tensile stresses in $\mathrm{Pa}$ ).

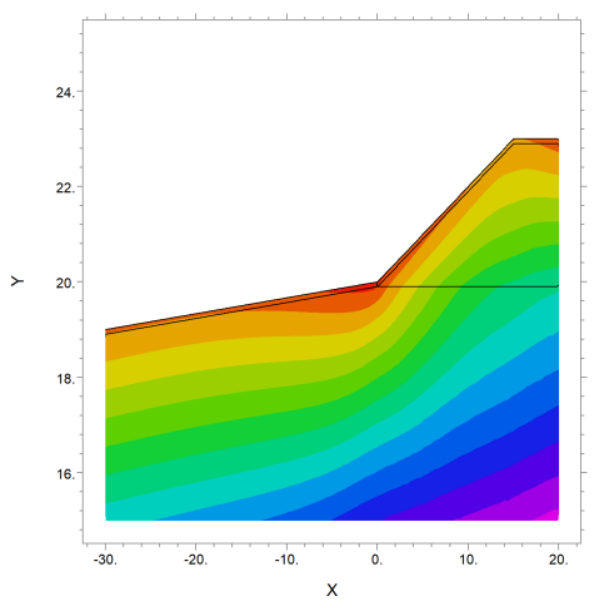

(a)

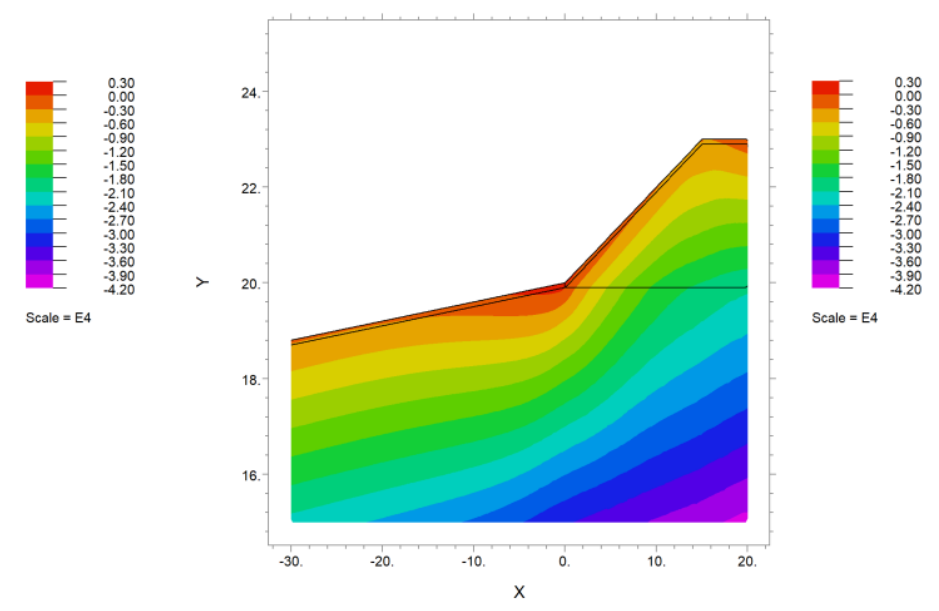

(b)

Figure 5. Cont. 


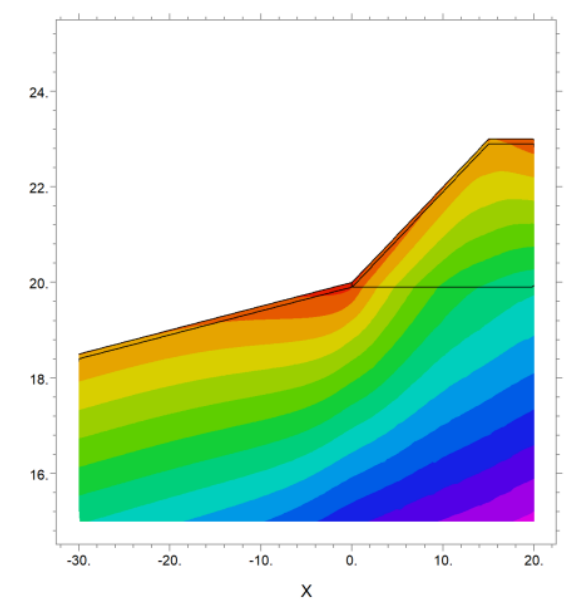

(c)

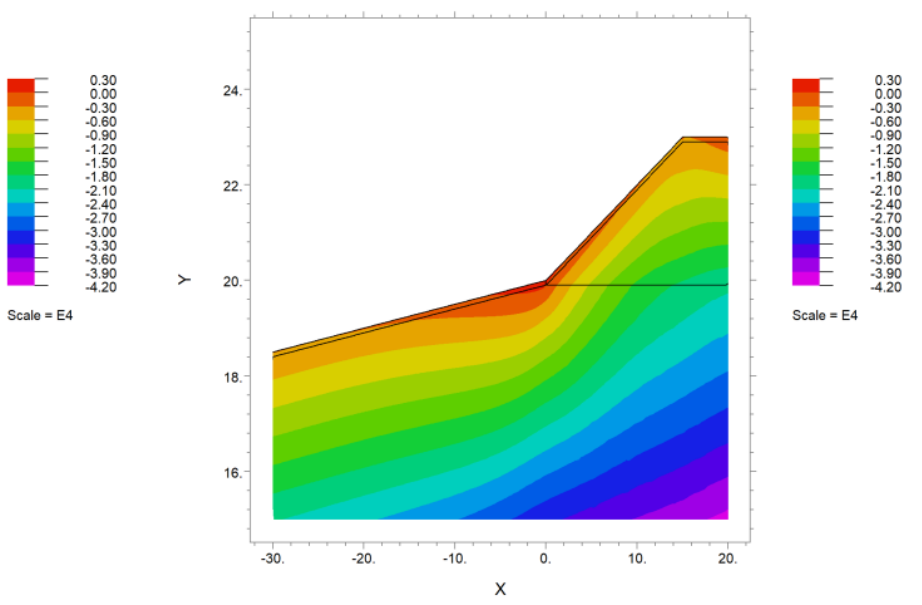

(d)

Figure 5. Horizontal stresses for the clay-type subsoil, for underwater slope inclinations of: (a) 1:30, (b) 1:25, (c) 1:20, (d) 1:15 (negative values indicate compressive stresses in $\mathrm{Pa}$, and positive values-tensile stresses in $\mathrm{Pa}$ ).

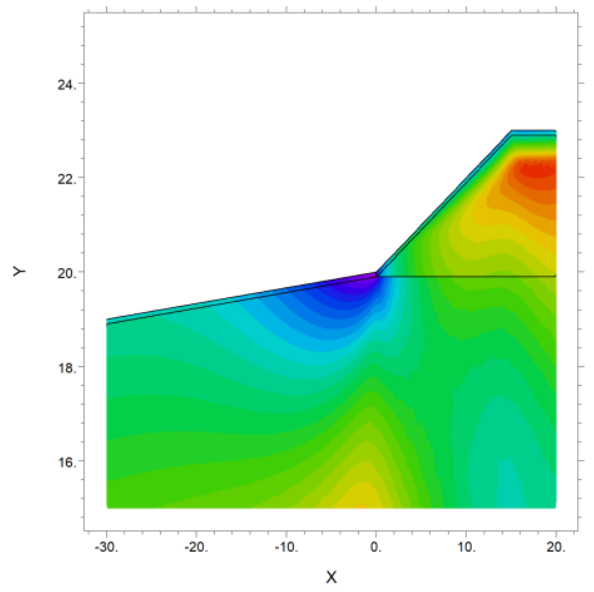

(a)

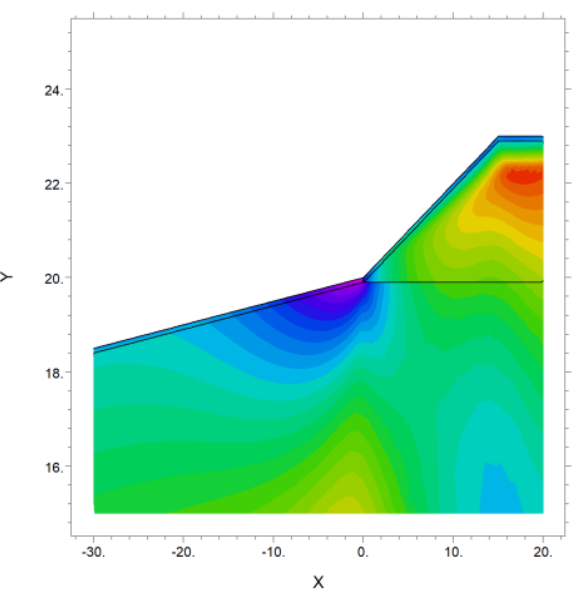

(c)

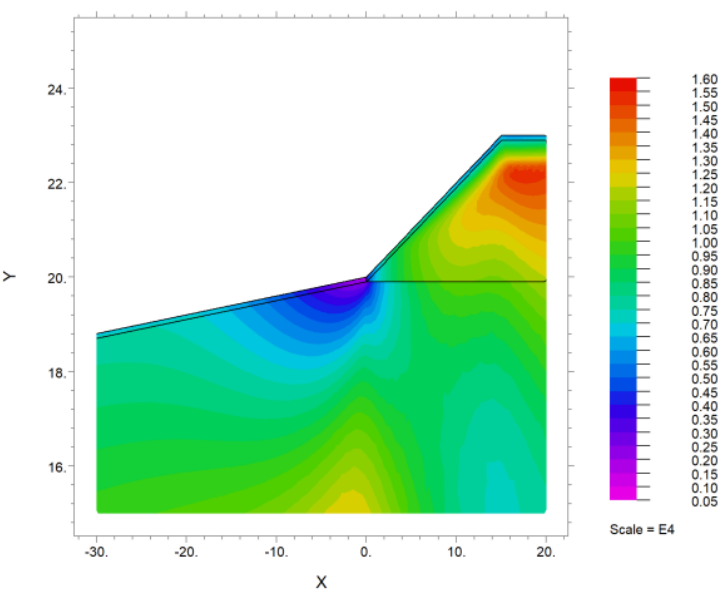

(b)
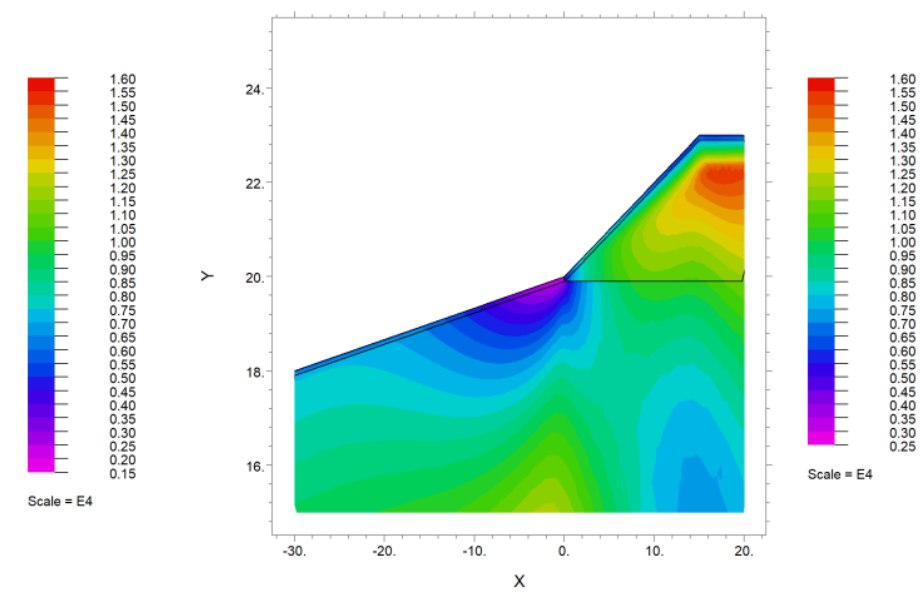

(d)

Figure 6. Coulomb-Mohr potential for the sand-type subsoil, for underwater slope inclinations of: (a) 1:30, (b) 1:25, (c) 1:20, (d) 1:15 (negative values indicate compressive stresses in $\mathrm{Pa}$, and positive values-tensile stresses in $\mathrm{Pa}$ ). 


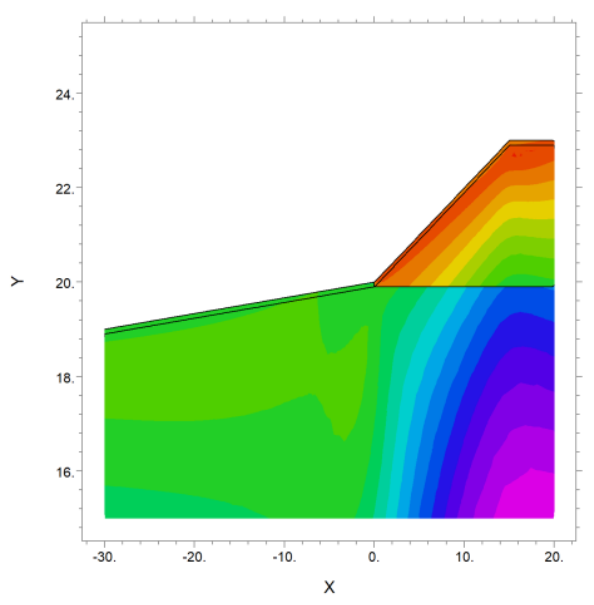

(a)

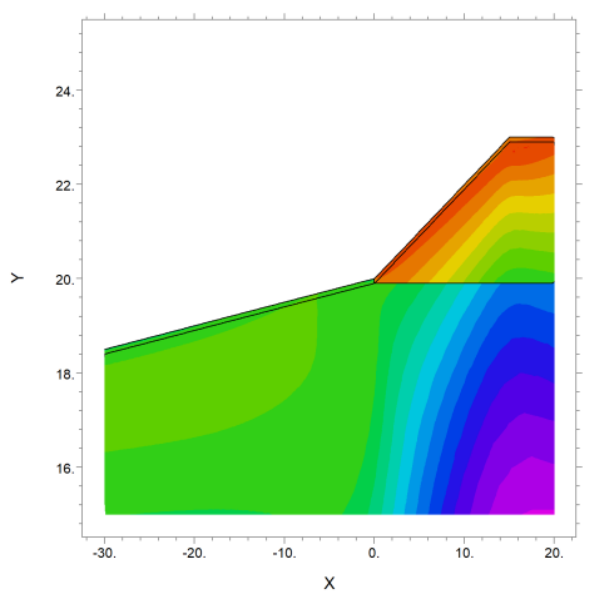

(c)

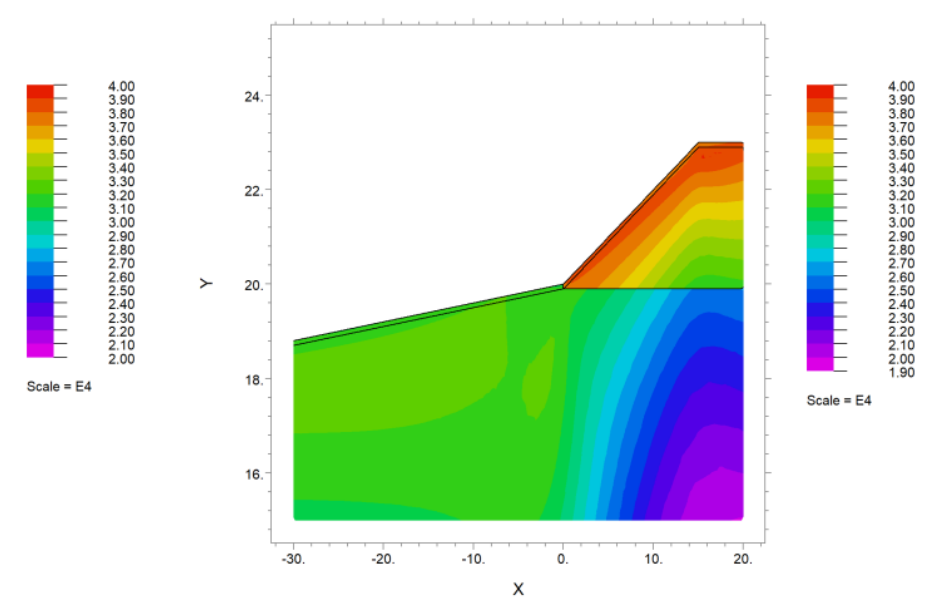

(b)
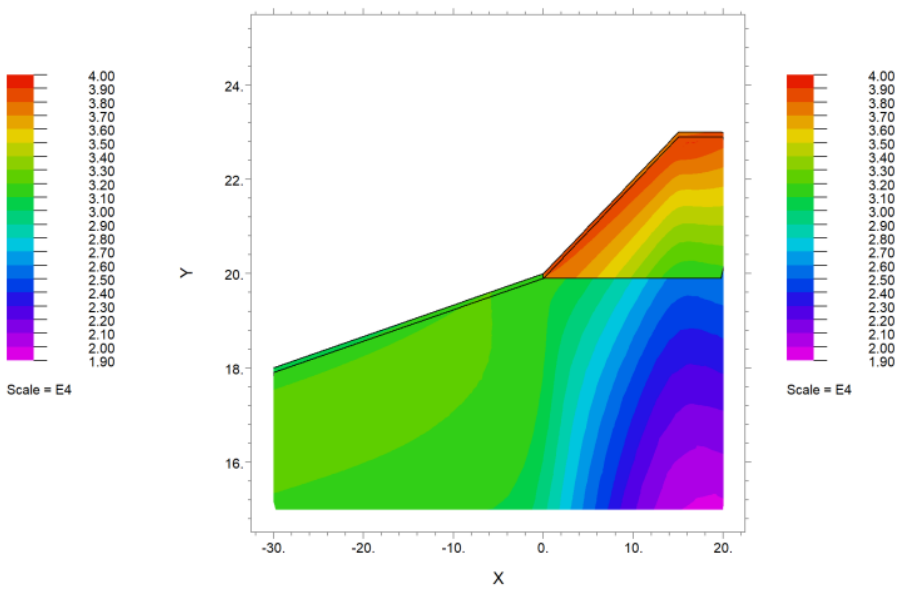

(d)

Figure 7. Coulomb-Mohr potential for the clay-type subsoil, for underwater slope inclinations of (a) 1:30, (b) 1:25, (c) 1:20, (d) 1:15 (negative values indicate compressive stresses in $\mathrm{Pa}$, and positive values - tensile stresses in $\mathrm{Pa}$ ).

In addition, Figure 8 shows shear stresses obtained from the calculated directions of main stresses for the greatest assumed inclinations of the underwater slope. The results suggest that the stability of the underwater slope is more important for the stability of the entire area, as the region beneath it is subjected to the highest shear stresses (the regions with a positive stress sign in Figure 8).

The slope stability analyses indicate that increased underwater slope inclination does not affect the stability of the slope system forming the beach and may by increased to as much as 1:15. Therefore, the recommended inclination of 1:30 does not seem to result from the soil strength conditions but from the expected comfort of the users. An additional note should be made that an inclination of 1:15 is an optimal solution in the case wherein the excavation depth renders an underwater slope with an inclination of 1:30 or less impossible. 


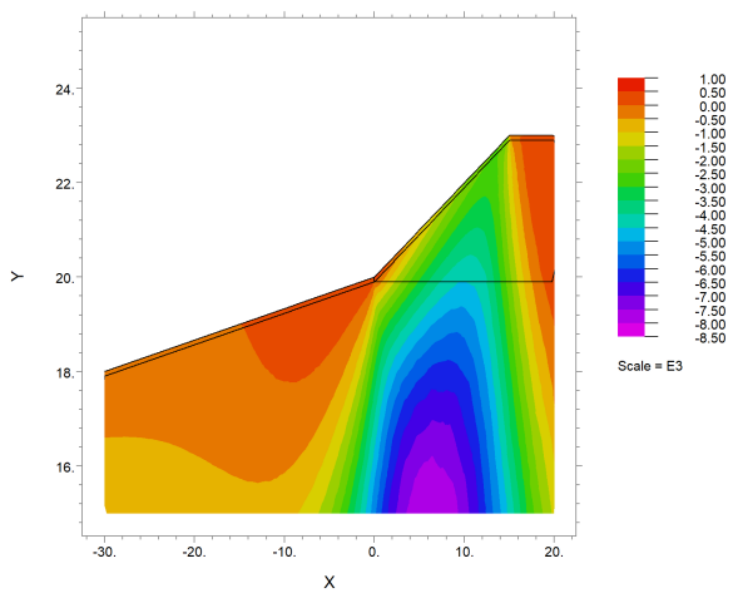

(a)

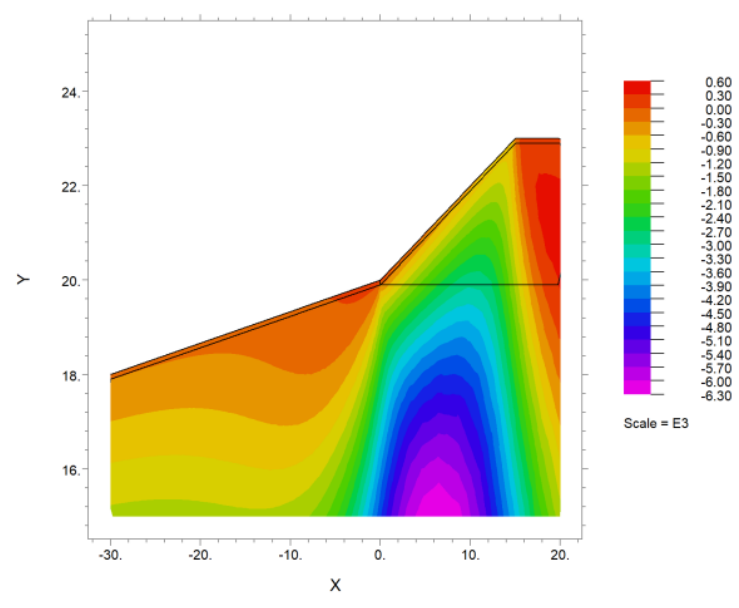

(b)

Figure 8. Shear stresses for the underwater slope inclination of 1:15: (a) clay-type subsoil, (b) sandtype subsoil (negative values indicate compressive stresses in $\mathrm{Pa}$, positive values-tensile stresses in $\mathrm{Pa}$ ).

\subsection{Inclination Optimization for Slopes Not Functioning as Beaches}

The inclination of a slope not functioning as a beach should be shaped with allowance for the stability conditions. Its basic function is to offer an anti-landslide protection, with water being an additional factor affecting its stability.

Section 3.1 demonstrated that in the case of recreational functions (beaches), the slope inclination may be significantly higher than recommended (Figure 2). Therefore, additional calculations were performed for underwater slope inclination ranges greater than those recommended for non-recreational functions (1:5). The above-waterline slope inclination was assumed at 1:2, and the underwater slope inclinations were assumed at 1:5, 1:4, 1:3, and 1:2, with the underwater slope height of $10 \mathrm{~m}$.

Figures 9 and 10 show horizontal stresses for clay and for coarse sand, respectively. The increasing of the inclinations within the assumed range did not influence the simulation results, with higher stresses observed for clay. From the perspective of slope stability, calculations of the Coulomb-Mohr potential are more important. They are shown for both types of soil in Figures 11 and 12. The potential sign was not observed to reverse in any area, which suggests good stability conditions for both underwater and above-water slopes, for both media. 


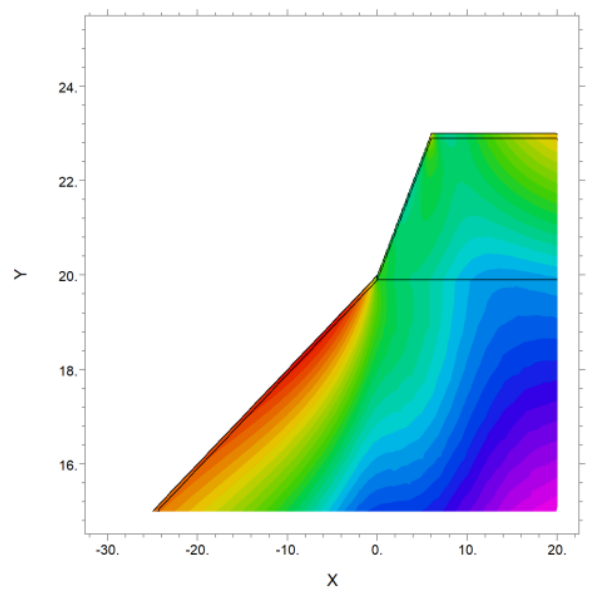

(a)

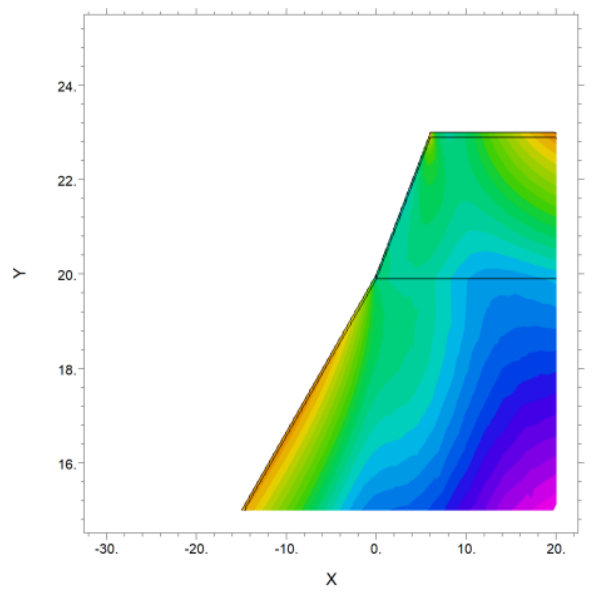

(c)
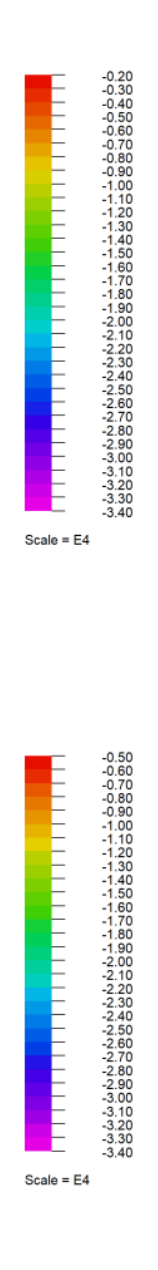

Figure 9. Horizontal stresses for the sand-type subsoil, for underwater slope inclinations of: (a) 1:5, (b) 1:4, (c) 1:3, (d) 1:2 (negative values indicate compressive stresses in Pa, and positive values-tensile stresses in $\mathrm{Pa})$.

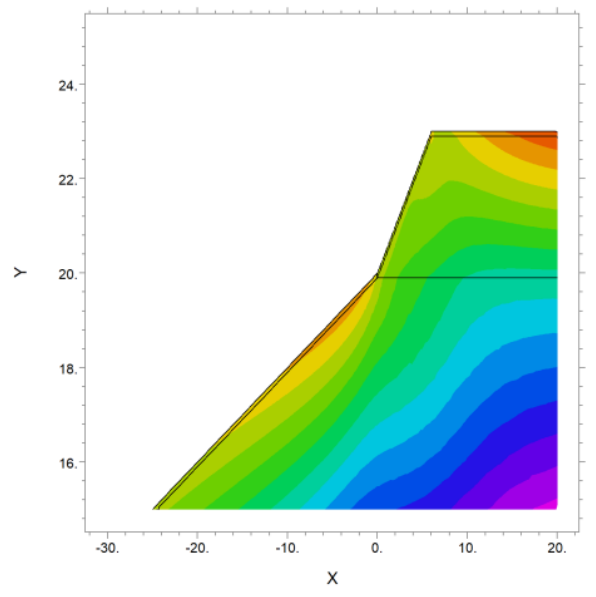

(a)

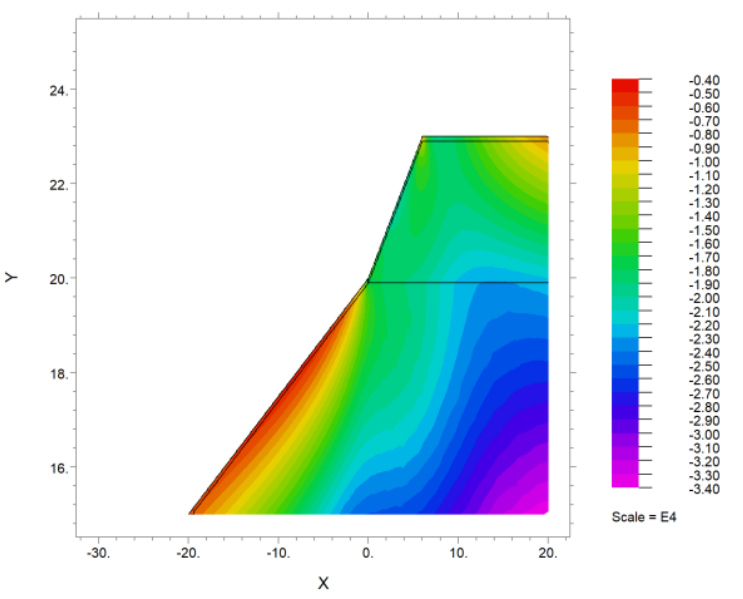

(b)

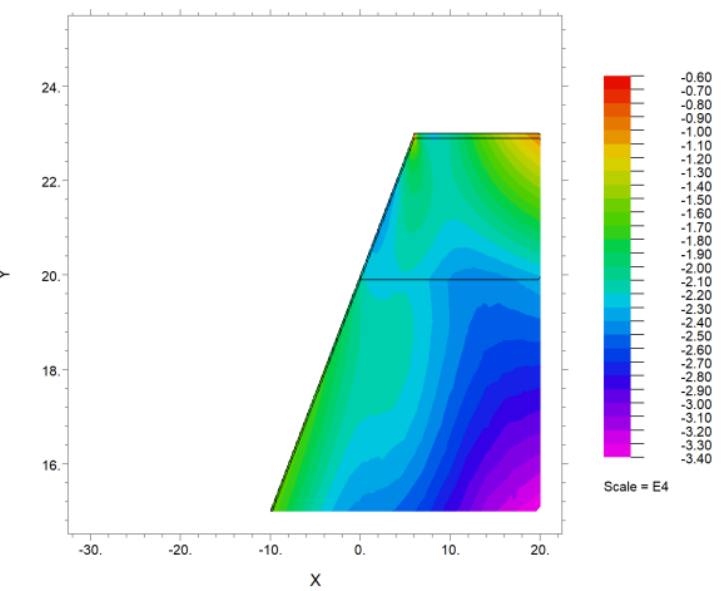

(d)

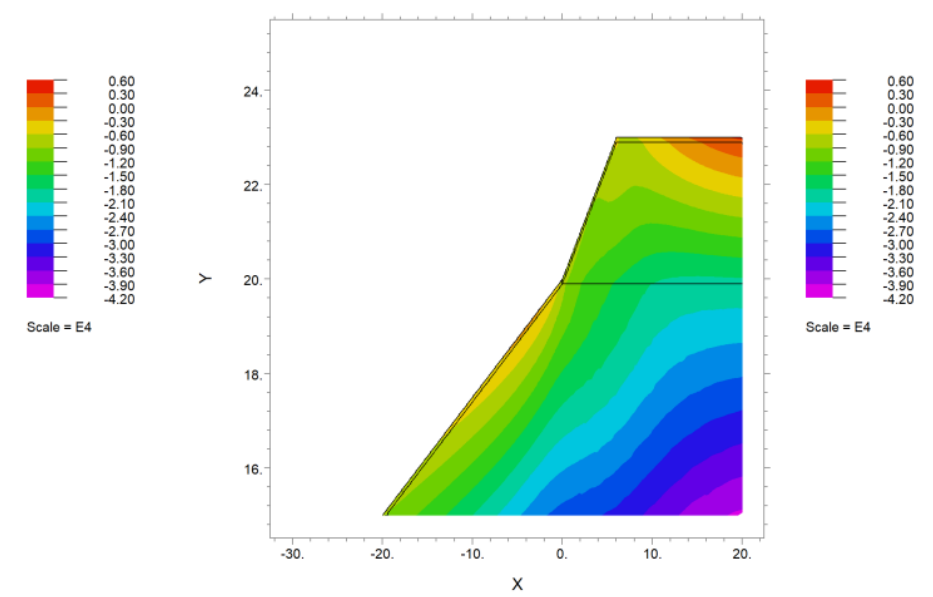

(b)

Figure 10. Cont. 


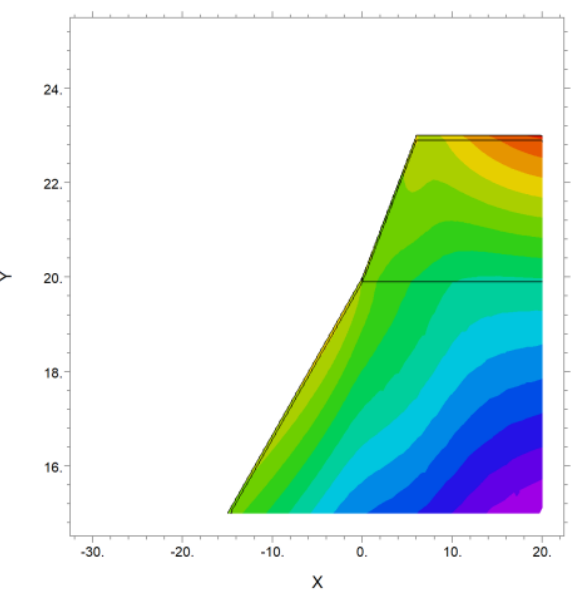

(c)

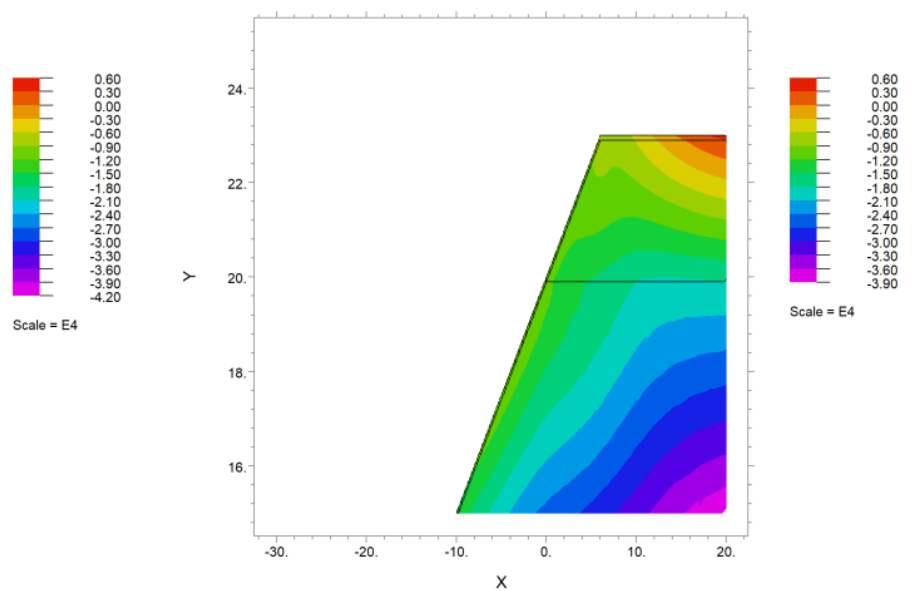

(d)

Figure 10. Horizontal stresses for the clay-type subsoil, for underwater slope inclinations of (a) 1:5, (b) 1:4, (c) 1:3, (d) 1:2 (negative values indicate compressive stresses in Pa, and positive values—tensile stresses in $\mathrm{Pa})$.

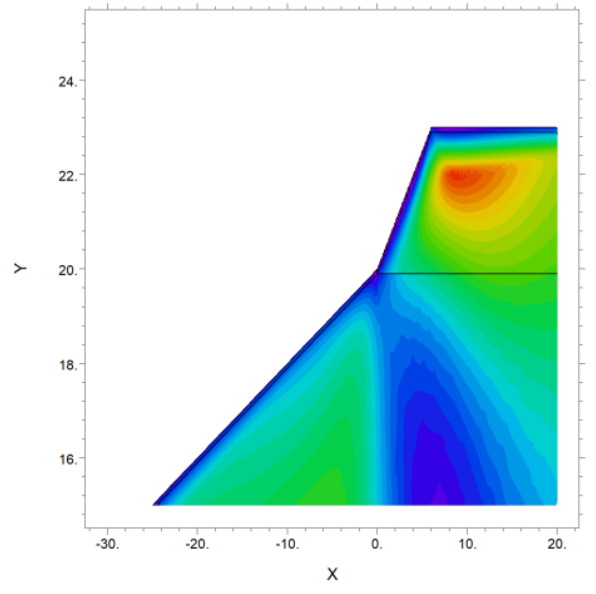

(a)

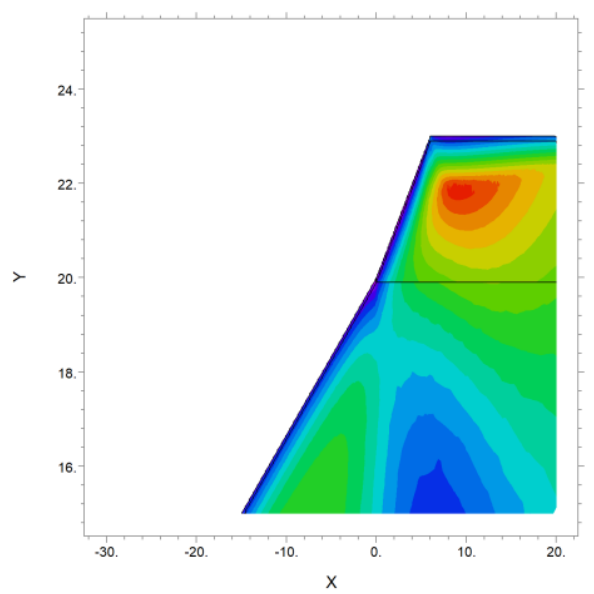

(c)
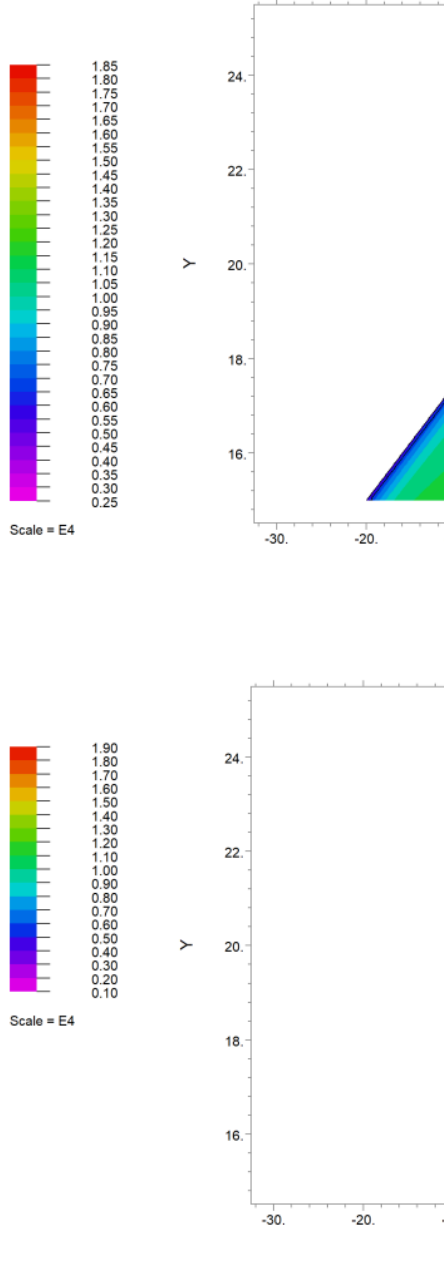

(b)

Figure 11. Coulomb-Mohr potential for the sand-type subsoil, for underwater slope inclinations of (a) 1:5, (b) 1:4, (c) 1:3, (d) 1:2 (negative values indicate compressive stresses in $\mathrm{Pa}$, and positive values-tensile stresses in $\mathrm{Pa})$. 


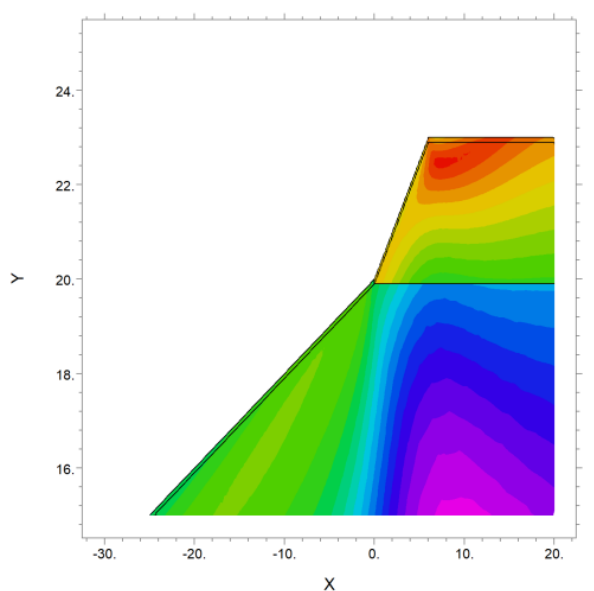

(a)

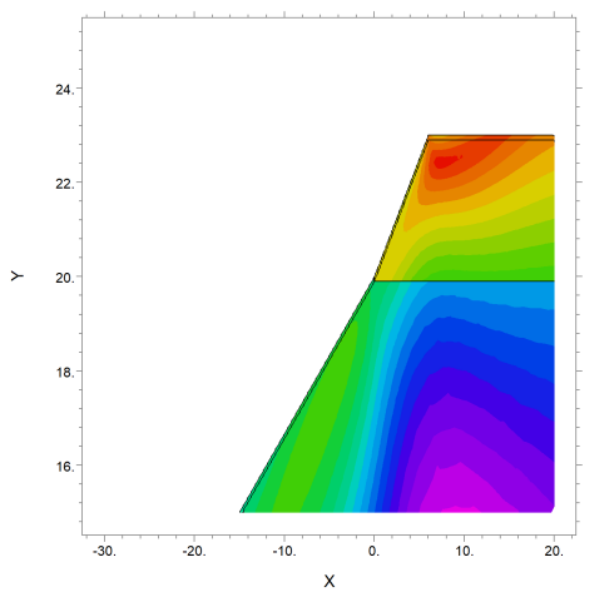

(c)

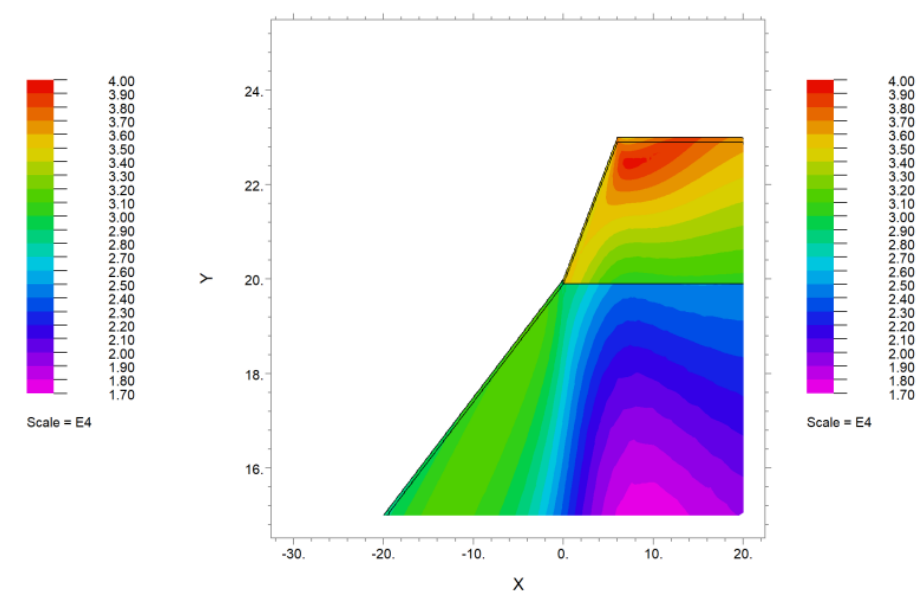

(b)

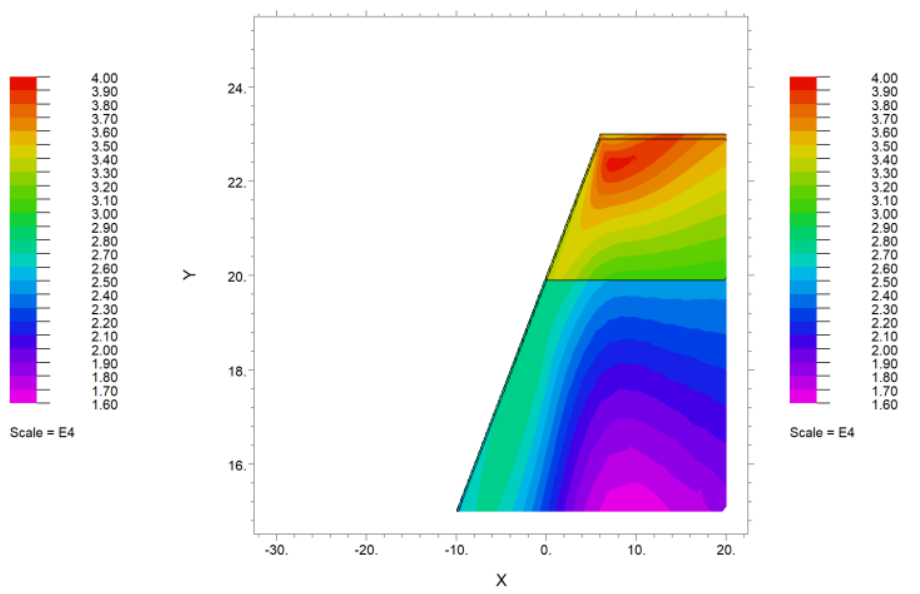

(d)

Figure 12. Coulomb-Mohr potential for the clay-type subsoil, for underwater slope inclinations of (a) 1:5, (b) 1:4, (c) 1:3, (d) 1:2 (negative values indicate compressive stresses in Pa, and positive values-tensile stresses in $\mathrm{Pa}$ ).

In addition, Figure 13 shows shear stresses obtained from the calculated directions of main stresses for the greatest assumed inclinations of the underwater slope. In the case of the above inclinations, the line of a potential slip surface can be identified-it takes the form of the highest (negative) shear stresses.

For comparison purposes, Figure 14 shows the results of calculations for a sandtype unstable slope, whose inclination in its both above-water and underwater parts was assumed at 1:1. The figure shows (a) the line along which the sign is reversed, indicating a potential slip surface; (b) shear stresses observed in the region. 


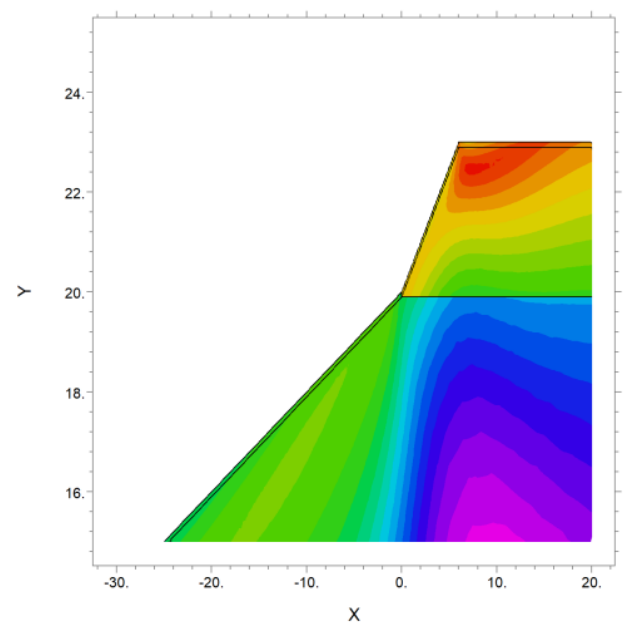

(a)

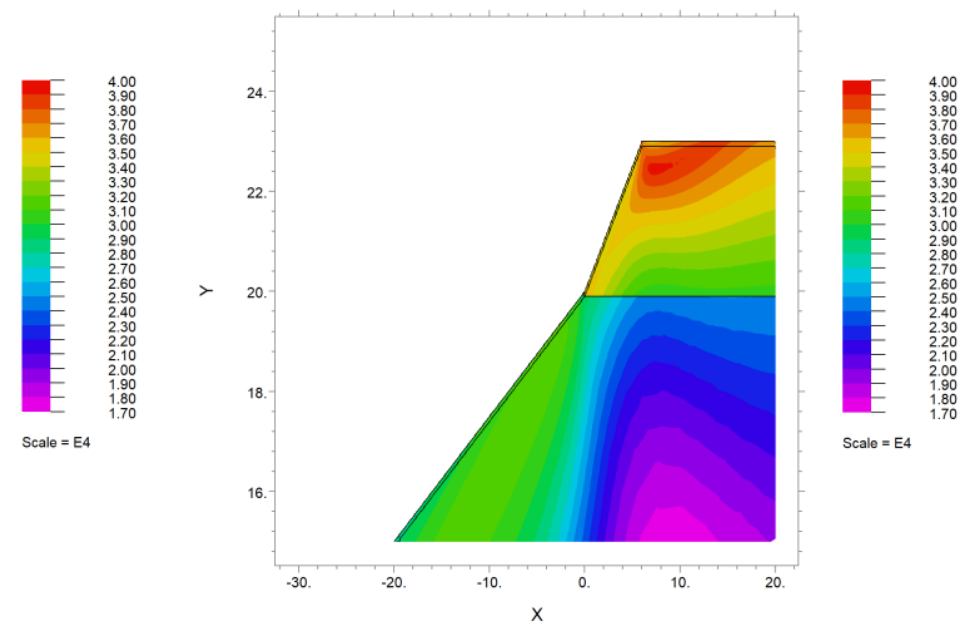

(b)

Figure 13. Shear stresses for the underwater slope inclination of 1:15-(a) clay-type subsoil, (b) sand-type subsoil.

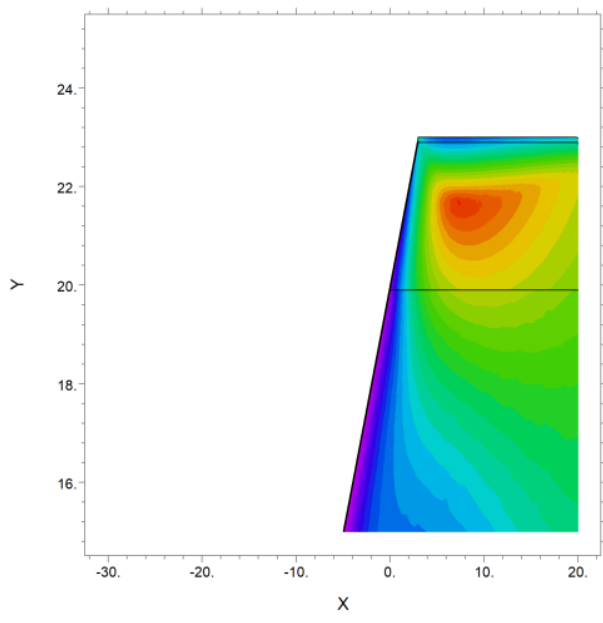

(a)

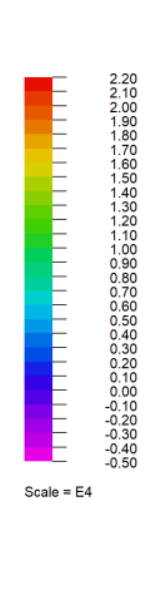
(b) shear stresses.

\section{Discussion and Conclusions}

Mining, as with other industries, needs to face the challenges of lowering its negative impact on the environment. Post-mining excavations, which are the leftovers after extracting mineral resources, are one of the most important ones. They require actions aimed at their reuse, and they cannot just be left and forgotten. This new usage includes a wide variety of options, which depend on the mining and geological as well as economic conditions $[5,7,11,16,29-35]$.

In the case wherein the groundwater table level is above the floor of the post-mining excavation, the potential for reuse becomes limited. The only justified solution in such a situation is to perform the reclamation process in the aquatic direction or for fish production. Using such areas for other purposes (e.g., as forest lands) is technically possible, of course, but the necessary tasks (raising the floor of the excavation) would entail significant financial expenditures. Solutions of this kind are uneconomic.

In their publications, Strzałkowski and Kaźmierczak [12,14,15] proposed slope inclinations for excavations reclaimed in the aquatic direction. Although the results of that research are correct, the authors suggest that the reclamation scope of works and costs 
might be lower if different slope inclinations are used. The analyses of stability and loadbearing capacity of the excavation slopes confirm the justification of such actions. The optimal inclinations for the above-waterline and below-waterline slopes which serve a beach function are now proposed at 1:5 and 1:15, respectively (Figure 15). This solution will allow a twofold or even fourfold smaller scope of the reclamation works related to moving earth masses in order to shape the slopes (depending on the chosen inclination of 1:30-1:60). Despite their increased inclination, the slopes functioning as beaches will still prove stable and safe while also comfortable to use. In the case of water reservoirs which are formed in old excavations of clastic rocks and clays and which are not intended to function as beaches, the optimal inclination for both underwater and above-water slopes is $1: 2$.

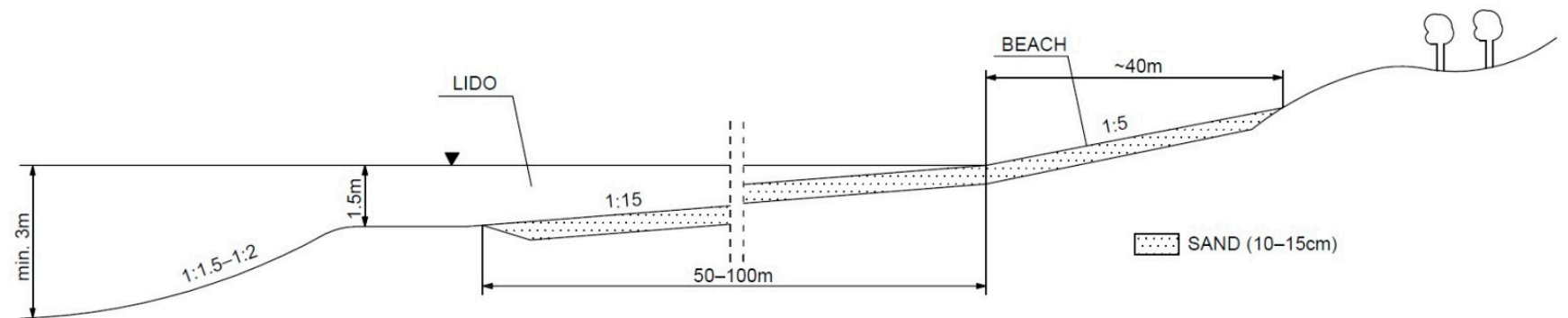

Figure 15. Profile of a lido in an old excavation of rock raw materials with the proposed new slope inclinations.

Importantly, the analyses presented here are hypothetical; therefore, the potential for reducing the slope inclination should be analyzed individually for each case, allowing for the actual geological and mining parameters. The economic aspect, which significantly influences the cost of slope shaping works, should also be considered.

Therefore, taking into account the research conducted and its results, further research directions can be proposed, which should be: the parametric studies with different soil parameters and the analysis of reclamation costs related to the proposed optimization of reclamation works and the determination of limit slopes related to safe use of the slopes of water reservoirs after the exploitation of mineral resources.

Author Contributions: Conceptualization, U.K.; methodology, U.K. and M.B.-U.; software, M.B.-U.; validation, U.K., for-mal analysis, U.K. and P.S.; investigation, U.K., P.S. and M.B.-U.; resources, U.K. and M.B.-U.; data curation, U.K. and M.B.-U.; writing-U.K., M.B.-U. and P.S.; review and editing, U.K., M.B.-U. and P.S.; visualization, M.B.-U. and P.S.; supervision, U.K.; project administration, P.S.; funding acquisition, U.K. and P.S. All authors have read and agreed to the published version of the manuscript.

Funding: This research was funded by the Polish Ministry of Education and Science Subsidy 2022.

Institutional Review Board Statement: Not applicable.

Informed Consent Statement: Not applicable.

Data Availability Statement: Not applicable.

Conflicts of Interest: The authors declare no conflict of interest.

\section{References}

1. Kaźmierczak, U.; Malewski, J. On reclamation cost in surface mining. Pr. Nauk. Inst. Górnictwa Politech. Wrocławskiej Studia I Mater. 2002, 29, 105-112. (In Polish)

2. Kaźmierczak, U.; Malewski, J.; Strzałkowski, P. Financial effects of reclamation commitment in rock mining. Górnictwo Odkryw. 2015, 56, 9-13. (In Polish)

3. Kaźmierczak, U.; Malewski, J.; Strzałkowski, P. The Concept of Forecasting the Reclamation Cost in Rock Mining. Gospod. Surowcami Miner.-Miner. Resour. Manag. 2019, 35, 5-30. [CrossRef] 
4. Uberman, R.; Uberman, R. Closure of Mines and Reclamation of Post-Mining Areas in Opencast Mining. Technical, Legal and Financial Problems; IGSMiE PAN: Kraków, Poland, 2010; 132p. (In Polish)

5. Bobrek, K.; Paulo, A. Problems with reclamation of post-mining pits: Soła valley between Kęty and Bielany-Case study. Geologia 2005, 31, 153-165. (In Polish)

6. Ciepielowski, A. Podstawy Gospodarowania Woda; SGGW: Warszawa, Poland, 1999; 326p.

7. Król, L. Legal and technical constraints to construction of fish farming ponds and incompatibility of related exploitation of aggregates. Gospod. Surowcami Miner.-Miner. Resour. Manag. 2005, 21, 83-88. (In Polish)

8. Glapa, W.; Jonek, W. Implements of worked out open pit mines in natural Aggregate mining. Górnictwo Odkryw.-Surf. Min. 1998, 40, 97-107. (In Polish)

9. Paulo, A. Economical and natural conditions applicable to the development of post-mining areas. Pol. Geol. Inst. Spec. Pap. 2005, 17, 49-69.

10. Chodak, M. Metody Rekultywacji i Zagospodarowania Obszarów Poeksploatacyjnych w Górnictwie Skalnym; Poltegor-Instytut Instytut Górnictwa Odkrywkowego: Kraków-Wrocław, Poland, 2013; 112p. (In Polish)

11. Kalybekov, T.; Sandibekov, M.; Rysbekov, K.; Zhakypbek, Y. Substantiation of ways to reclaim the space of the previously mined-out quarries for the recreational purposes. In E3S Web of Conferences; EDP Sciences: Les Ulis, France, 2019; Volume 123, pp. 1-13.

12. Kaźmierczak, U.; Strzałkowski, P. Scope of reclamation works in aquatic direction areas after the exploitation of rock raw materials. Bull. Miner. Energy Econ. Res. Inst. Pol. Acad. Sci. 2016, 94, 127-136. (In Polish)

13. Maciak, F. Ochrona i Rekultywacja Środowiska; SGGW: Warszawa, Poland, 1999; p. 466. (In Polish)

14. Strzałkowski, P.; Kaźmierczak, U. Reclamation of post-mining areas of rock minerals in aquatic objective. In Interdyscyplinarne Zagadnienia w Górnictwie i Geologii; Drzymała, J., Ed.; Wydział Geoinżynierii, Górnictwa i Geologii Politechniki Wrocławskiej: Wrocław, Poland, 2014; pp. 225-229. (In Polish)

15. Strzałkowski, P.; Kaźmierczak, U. The Scope of Reclamation Works for Areas after the Exploitation of Rock Raw Materials. Appl. Sci. 2019, 9, 1181. [CrossRef]

16. Šofranko, M.; Végsöová, O.; Kalász, T.; Sulovec, V.; Beca, J.; Šuver, M. Effect of Reclamation on an Environment Impaired by Mining Activity: A Case Study. Pol. J. Environ. Stud. 2020, 29, 29-37. [CrossRef]

17. Worlanyo, A.S.; Jiangfeng, L. Forthcoming. Evaluating the environmental and economic impact of mining for post-mined land restoration and land-use: A review. J. Environ. Manag. 2021, 279, 1-16. [CrossRef] [PubMed]

18. Chwastek, J. Surface Protection and Reclamation in Opencast Mining; Politechnika Wrocławska: Wrocław, Poland, 1972; 156p. (In Polish)

19. Yu, X.; Gong, B.; Tang, C. Study of the slope deformation characteristics and landslide mechanisms under alternating excavation and rainfall disturbance. Bull. Eng. Geol. Environ. 2021, 80, 7171-7191. [CrossRef]

20. Han, H.; Shi, B.; Zhang, L. Prediction of landslide sharp increase displacement by SVM with considering hysteresis of groundwater change. Eng. Geol. 2021, 280, e105876. [CrossRef]

21. Li, Q.; Wang, Y.M.; Zhang, K.B.; Yu, H.; Tao, Z.Y. Field investigation and numerical study of a siltstone slope instability induced by excavation and rainfall. Landslides 2020, 17, 1485-1499. [CrossRef]

22. Li, C.D.; Fu, Z.Y.; Wang, Y.; Tang, H.M.; Yan, J.F.; Gong, W.P.; Yao, W.M.; Criss, R.E. Susceptibility of reservoir-induced landslides and strategies for increasing the slope stability in the Three gorges reservoir area: Zigui basin as an example. Eng. Geol. 2019, 261, e105279. [CrossRef]

23. Butcher, A.; Stork, A.L.; Verdon, J.P.; Kendall, J.-M.; Plenkers, K.; Booth, F.; Boneham, M.; Koe, A. Evaluating rock mass disturbance within open-pit excavations using seismic methods: A case study from the Hinkley Point C nuclear power station. J. Rock Mech. Geotech. Eng. 2021, 13, 500-512. [CrossRef]

24. Troncone, A.; Pugliese, L.; Conte, E. Analysis of an excavation-induced landslide in stiff clay using the material point method. Eng. Geol. 2022, 296, e106479. [CrossRef]

25. Zhang, Z.; Fu, X.; Sheng, Q.; Du, Y. Stability of Cracking Deposit Slope Considering Parameter Deterioration Subjected to Rainfall. Int. J. Geomech. 2021, 21. [CrossRef]

26. Mandl, G. Faulting in Brittle Rocks. An Introduction to the Mechanics of Tectonic Fauls; Springer: Berlin/Heidelberg, Germany, 2000; 64p.

27. Labuz, J.F.; Zang, A. Mohr-Coulomb Failure Criterion. Rock Mech. Rock Eng. 2012, 45, 975-979. [CrossRef]

28. Cudny, M.; Binder, K. On shear strength criteria for soils in geotechnics. Inżynieria Morska Geotech. 2005, 6, 456-465. (In Polish)

29. Biny-Yuan, H.; Li-Xun, K. Mine Land Reclamation and Eco-Reconstruction in Shanxi Province I: Mine Land Reclamation Model. Sci. World J. 2014, 24, 1-9. [CrossRef] [PubMed]

30. Chudzik, W. The process of mined land reclamation in natural aggregate quarries exemplified by the sand and gravel quarry Dębina Łętowska. AGH J. Min. Geoengin. 2012, 26, 89-96.

31. Ignatyeva, M.; Yurak, V.; Pustokhina, N. Recultivation of Post-Mining Disturbed Land: Review of Content and Comparative Law and Feasibility Study. Resources 2020, 9, 73. [CrossRef]

32. Manero, A.; Kragt, M.; Standish, R.; Miller, B.; Jasper, D.; Boggs, G.; Young, R. A framework for developing completion criteria for mine closure and rehabilitation. J. Environ. Manag. 2020, 273, 111078. [CrossRef] 
33. Palogos, I.; Galetakis, M.; Roumpos, C.; Pavloudakis, F. Selection of optimal land uses for the reclamation of surface mines by using evolutionary algorithms. Int. J. Min. Sci. Technol. 2017, 27, 491-498. [CrossRef]

34. Stefanidis, P.; Stefanidis, S.; Tziaftani, F. The threat of alluviation of lakes resulting from torrents (case study: Lake Volvi, north Greece). Int. J. Sustain. Dev. Plan. 2011, 6, 325-335. [CrossRef]

35. Schleiss, A.J.; Franca, M.J.; Juez, C.; De Cesare, G. Reservoir sedimentation. J. Hydraul. Res. 2016, 54, 595-614. [CrossRef] 